Artikel Penelitian

\title{
Karakteristik Fisik-Kimia dan Aktivitas Antioksidan Ekstrak Etanolik Kulit Bawang Merah (Allium ascalonicum L.) Yang Diekstrak Menggunakan Microwave-Assisted Extraction
}

Physico-chemical Characteristics and Antioxidant Activity of Ethanolic Extract of Shallot Skin Extracted Using Microwave-Assisted Extraction

Erryana Martati ${ }^{\star}$, Gabriella Maharani Simamora

Program Studi IImu dan Teknologi Pangan, Fakultas Teknologi Pertanian, Universitas Brawijaya, Malang

*Korespondensi dengan penulis (erryana_m@ub.ac.id)

Artikel ini dikirim pada tanggal 10 Februari 2020 dan dinyatakan diterima tanggal 20 Februari 2021. Artikel ini juga dipublikasi secara online melalui https://ejournal2.undip.ac.id/index.php/jatp. Hak cipta dilindungi undang-undang. Dilarang diperbanyak untuk tujuan komersial Diproduksi oleh Indonesian Food Technologists® @2021

\begin{abstract}
Abstrak
Kulit bawang merah (Allium ascalonicum L.) mengandung senyawa fitokimia yang bisa berfungsi sebagai antioksidan. Tujuan penelitian ini adalah mempelajari pengaruh konsentrasi etanol dan lama ekstraksi terhadap karakteristik fisik-kimia ekstrak kulit bawang merah menggunakan microwave-assisted extraction. Penelitian ini menggunakan Rancangan Acak Kelompok (RAK) dengan dua faktor yaitu faktor konsentrasi etanol (70, 80, dan $90 \%$ ) dan lama waktu ekstraksi (10, 20 dan 30 menit). Setiap kombinasi perlakuan diulang tiga kali. Hasil penelitian menunjukkan konsentrasi etanol memberikan pengaruh yang nyata $(a=0,05)$ terhadap total fenol, total flavonoid, aktivitas antioksidan, sifat kemerahan $\left(a^{*}\right)$ dan kekuningan $\left(b^{*}\right)$. Kondisi ekstraksi yang optimum untuk kulit bawang merah adalah $70 \%$ etanol dan lama ekstraksi 20 menit. Ekstrak yang dihasilkan mempunyai karakteristik sebagai berikut: total fenol 31,34 $\pm 2,28 \mathrm{mg} \mathrm{GAE} / \mathrm{g}$; total flavonoid $26,12 \pm 0,75 \mathrm{mg} \mathrm{QE} / \mathrm{g}$; dan aktivitas antioksidan sebesar $65,94 \pm 0,55 \%$, nilai kecerahan $\left(L^{*}\right) 26,2 \pm 0,12$; nilai kemerahan $\left(a^{*}\right)-1,0 \pm 0,44$; nilai kekuningan $\left(b^{*}\right) 3,6 \pm 0,17$. Kesimpulannya, konsentrasi etanol dan lama ekstraksi mempengaruhi sifat fisik-kimia ekstrak kulit bawang merah.

Kata kunci: ektraksi; kulit bawang merah; senyawa antioksidan; microwave-assisted extraction

\section{Abstract}

Shallot skin (Allium ascalonicum L.) contains phytochemicals that can be a source of natural antioxidants. This research was done to study ethanol concentration and extraction time on the physicochemical characteristic of shallot skin extract using microwave-assisted extraction. This research used Randomized Block Design with two factors that were ethanol concentration (70, 80 and 90\%) and extraction time (10, 20 and 30 min.). Each combination of the treatment was repeated in three times. The results showed that ethanol concentration and extraction time gave significant effect $(a=0.05)$ on total phenol, total flavonoids, antioxidant activity, redness $\left(a^{*}\right)$, and yellowish $\left(b^{*}\right)$. The optimum extraction condition for shallot skin was $70 \%$ ethanol and $20 \mathrm{~min}$ of extraction. The extract had characteristics as follows: total phenol $31.34 \pm 2.28 \mathrm{mg}$ GAE/g; total flavonoid $26.12 \pm 0.75 \mathrm{mg}$ QE/g; antioxidant activity $65.94 \pm 0.55 \%$, brightness value $\left(L^{*}\right)$ of $26.2 \pm 0.12$; redness value $\left(a^{*}\right)$ of $-1.0 \pm 0.44$; yellowish value $\left(b^{*}\right)$ of $3.6 \pm$ 0.17 . As conclusion, ethanol concentration and extraction time affected physicochemical characteristic of shallot skin extract.
\end{abstract}

Keywords: extraction; shallot skin; antioxidant compounds; microwave-assisted extraction

\section{Pendahuluan}

Kulit bawang merah (Allium ascalonicum L.) selama ini belum dimanfaatkan padahal mengandung flavonoid kuersetin sebanyak $111,50 \mathrm{mmol} / \mathrm{g}$ yang mempunyai aktivitas antioksidan (Wiczkowski et al., 2008). Paparan senyawa toksik yang semakin meningkat dari lingkungan atau makanan ke dalam tubuh menyebabkan kemampuan sel hati untuk melakukan detoksifikasi senyawa toksik semakin menurun (Schrenk et al., 2020). Beberapa fitokimia mampu berfungsi sebagai kemo-preventif terjadinya kanker (Koh, 2020). Flavonoid kuersetin yang banyak ditemukan dalam bawang merah secara in vitro dan in vivo telah terbukti sebagai anti kanker (Tang et al., 2020). Radikal dalam tubuh menyebabkan terbentuknya kerusakan DNA yang selanjutnya menyebabkan meningkatnya resiko pembentukan malignan sel, proliferasi sel dan tahap promosi tumor, proses ini bisa dicegah dengan konsumsi fitokimia sebagai antioksidan (Bartsch and Gerhäuser, 2009). Fitokimia dalam kulit bawang merah mempunyai potensi dimanfaatkan menjadi ekstrak sebagai sumber antioksidan yang selanjutnya bisa dimanfaatkan sebagai nutrasetikal atau suplemen makanan.

Metode ekstraksi konvensional memerlukan waktu lama, suhu relatif lebih tinggi dan efisiensi rendah sehingga jumlah ekstrak yang dihasilkan rendah dan resiko kerusakan senyawa bioaktif yang bersifat tidak stabil sangat besar (Chan et al., 2011). Metode ekstraksi non-konvensioanal telah banyak dikembangkan untuk mengatasi masalah tersebut antara lain microwave assisted extraction (MAE). Mekanisme kerja MAE adalah adanya panas dari gelombang mikro yang berasal dari rotasi dipol pelarut polar dan induksi ionik 
yang terlarut di sistem menyebabkan timbulnya panas yang selanjutnya bisa menghancurkan matriks sel bahan dan membebaskan komponen ke pelarut (Yuan and Macquarrie, 2015). Pelarut polar seperti etanol, air dan metanol mempunyai kemampuan menyerap energi gelombang mikro sehingga mempunyai kemampuan ekstraksi yang tinggi dan mempunyai interaksi yang kuat dengan matriks dan target senyawa bioaktif (Tatke and Jaiswal, 2011). Hasil peneliitan ekstraksi kulit bawang merah dengan metode maserasi selama 2 kali 24 jam menghasilkan ekstrak kental kulit bawang merah memiliki aktivitas antioksidan 15,44 ppm (Mardiah et al., 2017). Ekstraksi kulit bawang merah menggunakan etanol $60 \%$ dan metode ultrasound-assisted extraction (UAE) dengan lama waktu ekstraksi 60 menit menghasikan ekstrak dengan kadar kuersetin yang tertinggi (Thuy et al., 2020). Ekstraksi kuersetin kulit bawang dengan MAE memberikan kuersetin yang tertinggi dibanding dengan ekstraksi dengan metode UAE dan metode konvensional (Jin et al., 2011).

Kekuatan energi gelombang mikro sangat dipengaruhi oleh jenis pelarut yang mampu menyerap energi gelombang mikro dan mengubahnya menjadi energi panas yang selanjutnya bisa mempengaruhi efisiensi ekstraksi (Kappe, 2004). Etanol dan air adalah pelarut yang aman untuk ekstraksi tanaman dibanding dengan metanol yang bersifat toksik. Etanol dengan persentase yang tinggi memiliki konstanta dielektrik rendah sehingga mempunyai kapasitas yang rendah dalam menyerap energi gelombang mikro (Zekovic et al., 2016; Tatke and Jaiswal, 2011). Pelarut dengan konstanta dielektrik yang rendah maka suhu pelarut akan tetap rendah selama ektsraksi sehingga sangat sesuai untuk ekstraksi senyawa yang termolabil (Routray and Orsat, 2012). Aplikasi gelombang mikro yang semakin lama dapat meningkatkan rendemen ekstrak tetapi mempunyai dampak negatif yaitu senyawa fitokimia bisa terdegradasi (Alara et al., 2018), sehingga penelitian ini bertujuan untuk menganalisis ekstraksi kulit bawang merah dengan metode MAE dengan melihat pengaruh faktor konsentrasi etanol dan lama waktu ekstraksi terhadap karakteristik fisiko-kimia ekstrak. Penelitian ini sangat bermanfaat untuk mengoptimalkan sifat fungsional yang ada pada ekstrak kulit bawang untuk dapat digunakan sebagai sumber antioksidan.

\section{Materi dan Metode}

Materi

Bahan yang digunakan dalam penelitian ini adalah kulit bawang merah varietas Sembrani yang diperoleh dari pasar kota Batu. Asam galat, kuersetin dan asam tanat $\mathrm{Na}_{2} \mathrm{CO}_{3}, \mathrm{NaOH}, \mathrm{NaNO}_{2}, \mathrm{AlCl}_{3}$, larutan Folinciocalteu diperoleh dari Merck (US). DPPH (2,2diphenyl-1-picrylhydrazyl) diperoleh dari Sigma Aldrich (US). Alat yang digunakan untuk penelitian ini adalah microwave assisted extraction (MAE) (Anton Paar, Jerman), spektrofotometer UV-Vis (Shimadzu, Japan), timbangan analitik (Mettler Toledo, US) dan color reader (Konica Minolta, Japan).

\section{Metode Penelitian}

Penelitian berlangsung selama bulan Mei hingga Oktober 2019. Penelitian dilakukan di Laboratorium Teknologi Hasil Pertanian Universitas Brawijaya. Proses ekstraksi dengan alat ekstraksi MAE dilakukan di Laboratorium Sentral Ilmu Hayati Universitas Brawijaya. Rancangan percobaan yang digunakan Rancangan Acak Kelompok (RAK) dengan 2 faktor. Faktor pertama adalah konsentrasi etanol yaitu 70, 80, dan 90\%. Faktor kedua adalah waktu ekstraksi yaitu 10, 20 dan 30 menit.

\section{Pembuatan Serbuk Kulit Bawang Merah}

Kulit bawang merah disortasi kemudian dilakukan pencucian dengan air mengalir. Selanjutnya dikeringanginkan selama 3 hari. Kulit bawang yang telah kering dihancurkan dengan blender dan diayak dengan menggunakan ayakan 40 mesh. Serbuk kulit bawang merah disimpan pada suhu $-20^{\circ} \mathrm{C}$ sebelum dilakukan ekstraksi dan analisis.

\section{Ekstraksi Kulit Bawang Merah}

Proses ekstraksi dilakukan dengan kondisi ekstraksi kombinasi konsentrasi etanol dan lama waktu ekstraksi yang telah ditetapkan. Serbuk kulit bawang merah sebanyak $2 \mathrm{~g}$ ditambah dengan etanol sebanyak $30 \mathrm{ml}$, kemudian dimasukkan ke dalam tabung ekstraksi MAE. Ekstraksi dilakukan pada sistem tertutup dan pada suhu $50^{\circ} \mathrm{C}$. Setelah itu disaring dengan kertas saring untuk mendapatkan filtrat. Filtrat disimpan pada suhu $20^{\circ} \mathrm{C}$ hingga analisis tahap berikutnya.

\section{Analisis Total Fenol}

Sebanyak 0,5 ml sampel yang telah dilakukan pengenceran ditambahkan $2,5 \mathrm{ml}$ reagen FolinCiocalteau (1:10) kemudian divortex (Wolfe et al., 2003). Selanjutnya ditambah $2 \mathrm{ml} \mathrm{Na} \mathrm{CO}_{3} 7,5 \%$ dan divortex. Larutan diinkubasi selama 30 menit dalam kondisi gelap. Kemudian dilakukan pengukuran absorbansi menggunakan spektrofotometer UV-Vis pada panjang gelombang $765 \mathrm{~nm}$. Kurva standard asam galat dibuat seperti prosedur untuk sampel. Kadar total fenol dinyatakan sebagai ekuivalen $\mathrm{mg}$ asam galat (mg GAE).

\section{Analisis Total Flavonoid}

Sampel sebanyak $0,5 \mathrm{ml}$ ditambah $2 \mathrm{ml}$ akuades, kemudian ditambah $0,15 \mathrm{ml} \mathrm{NaNO} \mathrm{N}_{2} \%$ lalu divortex hingga homogen dan diinkubasi selama 6 menit. Sesudah itu ditambah $0,15 \mathrm{ml} \mathrm{AlCl}_{3} \quad 10 \%$ kemudian divortex hingga homogen dan diinkubasi selama 6 menit yang dilanjutkan dengan penambahan $1 \mathrm{ml} \mathrm{NaOH} 1 \mathrm{M}$ dan akuades sebanyak 1,2 $\mathrm{ml}$ akuades dan divortex hingga homogen dan diinkubasi selama 15 menit. Absorbansi larutan diukur menggunakan spektrofotometer UV-Vis pada panjang gelombang 510 $\mathrm{nm}$. Kadar total flavonoid dinyatakan sebagai ekivalen mg kuersetin (Patel et al., 2010).

\section{Analisa Statistik}

Data yang diperoleh dianalisa statistika Analysis of Variance (ANOVA) menggunakan program Minitab 17 untuk mengetahui ada atau tidaknya pengaruh pada 
setiap perlakuan terhadap parameter yang diuji. Apabila hasil uji pada tiap perlakuan menunjukkan beda nyata maka dilakukan uji lanjut dengan uji BNT (Beda Nyata Terkecil) $95 \%$ dan apabila terdapat interaksi antara kedua faktor perlakukan dilakukan uji lanjut dengan uji DMRT (Duncan's Multiple Range Test) menggunakan program Minitab 17.

\section{Hasil dan Pembahasan}

\section{Total Fenol Ekstrak Kulit Bawang Merah}

Rerata total fenol dengan perlakuan konsentrasi etanol dan lama ekstraksi dapat dilihat pada Figur 1. Hasil analisa ragam menunjukkan bahwa faktor waktu ekstraksi berpengaruh nyata $(a=0,05)$, sedangkan konsentrasi etanol tidak berpengaruh nyata terhadap nilai total fenol ekstrak. Ekstrak kulit bawang merah waktu ekstraksi 10 menit memiliki nilai total fenol terendah yaitu 21,24+1,97 mg GAE/g. Ekstraksi selama 10 menit, energi gelombang mikro belum mampu menghancurkan matrik sel bahan dan mengeluarkan senyawa fitokimia ke luar sistem pelarut sehingga senyawa fenol yang terekstrak kurang maksimal (Dahmoune et al., 2015), sedangkan waktu ekstraksi 20 dan 30 menit menghasilkan ekstrak dengan total fenol yang lebih tinggi yaitu berturur-turut 29,90 $\pm 2,07$ dan $27,46 \pm 0,88 \mathrm{mg} \mathrm{GAE} / \mathrm{g}$. Kedua nilai tersebut berbeda nyata dengan ekstrak dengan waktu ekstraksi 10 menit $(a=0,05)$. Paparan radiasi gelombang mikro selama 20 dan 30 menit menyebabkan pelarut memiliki waktu kontak yang cukup untuk dapat berdifusi ke dalam bahan sehingga mampu mengekstrak senyawa fenol dari bahan secara maksimal (Dahmoune et al., 2015; Tabaraki and Nateghi, 2011). Kondisi ini akan terus berlanjut hingga tercapai kondisi kesetimbangan antara konsentrasi senyawa fenol di dalam bahan baku dengan konsentrasi senyawa dalam pelarut (Zhang et al., 2018). Total fenol ekstrak kulit bawang merah dengan lama waktu ekstraksi 30 menit mengalami penurunan sedikit walaupun secara statistika $(a=0,05)$ tidak berbeda nyata. Hal ini sejalan dengan penelitian Pimentel et al. (2018) proses ekstraksi yang terlalu lama radiasi gelombang mikro dapat menurunkan rendemen ekstrak karena degradasi senyawa aktif fenol. Penelitian lain juga menunjukkan lama waktu ekstraksi lebih dari 15 menit menurunkan kadar fenol, kemungkinan disebabkan komponen lain selain fenol seperti karbohidrat dan mineral ikut terekstrak sehingga menurunkan konsentrasi relatif fenol (Filip et al., 2017; Pavlović et al., 2013; Milutinović et al., 2014; Milutinović et al., 2015; Simić et al., 2016).

\section{Total Flavonoid}

Rerata total flavonoid dengan perlakuan konsentrasi etanol dan lama ekstraksi dapat dilihat pada Figur 2. Hasil analisa ragam menunjukkan bahwa faktor waktu ekstraksi berpengaruh nyata $(a=0,05)$, sedangkan konsentrasi etanol tidak berpengaruh nyata terhadap nilai total flavonoid ekstrak dan tidak ada interaksi $(a=0,05)$ antara faktor konsentrasi etanol dan waktu ekstraksi pada nilai total flavonoid ekstrak kulit bawang merah.

Pada penelitian ini, etanol $70 \%$ dapat mengekstrak flavonoid lebih maksimal karena adanya kesesuaian tingkat kepolaran antara pelarut dan flavonoid (Routray and Orsat, 2012). Hal inilah yang menyebabkan nilai total flavonoid pada perlakuan konsentrasi etanol $70 \%$ dan $80 \%$ memiliki nilai yang lebih tinggi dibandingkan dengan perlakuan konsentrasi etanol $90 \%$. Hasil penelitian ini sejalan dengan penelitian Jin et al. (2011) yang menunjukkan ekstraksi kulit bawang menggunakan MAE dengan etanol 69,7\% menghasilkan flavonoid kuersetin yang tertinggi.

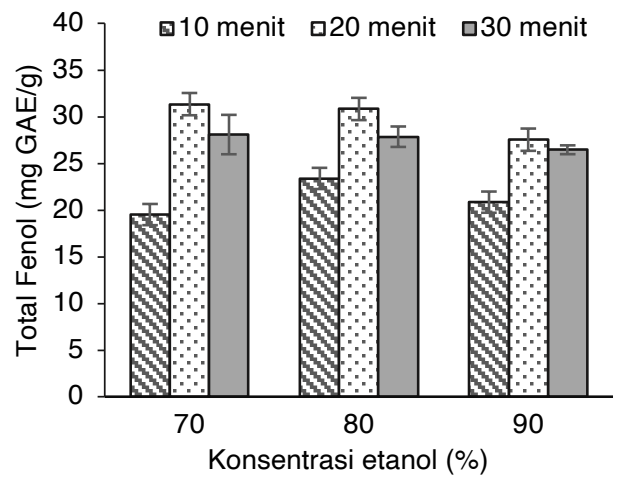

Figur 1. Grafik pengaruh konsentrasi etanol dan waktu ekstraksi terhadap nilai total fenol ekstrak kulit bawang merah

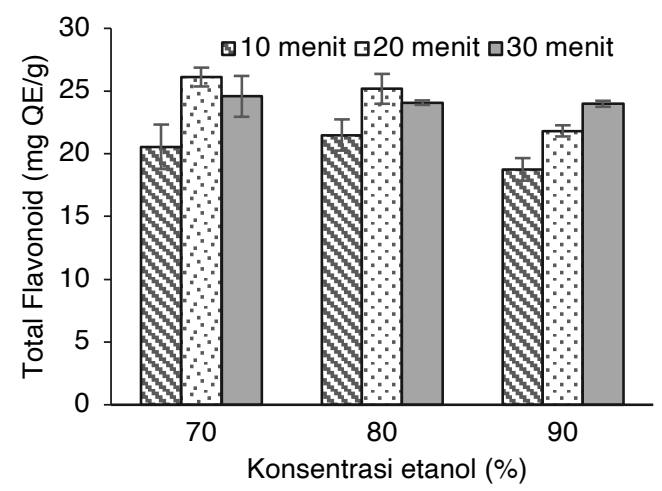

Figur 2. Grafik pengaruh konsentrasi etanol dan waktu ekstraksi terhadap nilai total flavonoid ekstrak kulit bawang merah

Hasil penelitian ini menunjukkan lama waktu ekstraksi 20 menit menghasilkan total flavonoid ekstrak tertinggi yaitu 24,38 $\pm 2,26 \mathrm{mg} Q \mathrm{QE} / \mathrm{g}$, sedangkan nilai terendah pada total flavonoid ekstrak yakni 20,27 $\pm 1,39$ mg QE/g pada waktu ekstraksi 10 menit. Fitokimia yang terekstrak cenderung akan meningkat dengan semakin lama waktu ekstraksi tetapi pada titik tertentu tidak akan terjadi peningkatan lagi (Wang et al., 2008). Ekstraksi kulit bawang dengan MAE, kuersetin mencapai maksimal pada lama ekstraksi 117 detik, sesudah itu mengalami penurunan (Jin et al., 2011). Paparan gelombang mikro yang semakin lama akan menyebabkan degradasi fitokimia akibat panas yang berlebih pada solut atau pelarut (Routray and Orsat, 2012).

Kuersetin merupakan flavonoid yang dominan dalam bawang merah, yaitu quercetin-3,4'-O-bis- $\beta$ - 
glucoside, quercetin-3-O- $\beta$-glucoside, quercetin-4'-O- $\beta$ glucoside, isorhamnetin-4'-O- $\beta$-glucoside, dan kuersetin non-glikon (Wiczkowski et al., 2008). Beberapa jenis flavonoid yang lain adalah kaempferol, isorhamnetin, apigenin-7-O- $\beta$-D-glucopyranoside, quercetin-3-O- $\beta-D$ glucopyranoside, kaemp-ferol -7-O- $\beta-D-$ glucopyranoside dan rutin (Shi et al., 2016).

\section{Aktivitas Antioksidan}

Figur 3 menunjukkan kecenderungan perubahan nilai aktivitas antioksidan ekstrak kulit bawang merah akibat pengaruh konsentrasi etanol dan waktu ekstraksi. Berdasarkan konsentrasi etanol, nilai aktivitas antioksidan ekstrak pada konsentrasi etanol $80 \%$ lebih tinggi dibanding pada konsentrasi etanol $90 \%$. Sedangkan semakin lama waktu ekstraksi pada masingmasing konsentrasi etanol, nilai aktivitas antioksidan ekstrak cenderung meningkat.

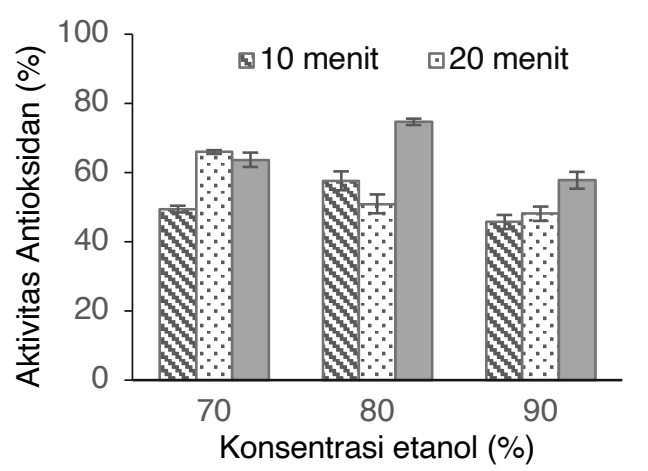

Figur 3. Grafik pengaruh konsentrasi etanol dan waktu ekstraksi terhadap aktivitas antioksidan ekstrak kulit bawang merah

Hasil analisa ragam menunjukkan bahwa faktor konsentrasi etanol dan waktu ekstraksi berpengaruh nyata $(a=0,05)$ terhadap nilai aktivitas antioksidan ekstrak. Kedua faktor tersebut terdapat interaksi $(a=0,05)$ antara faktor konsentrasi etanol dan waktu ekstraksi pada nilai aktivitas antioksidan ekstrak kulit bawang merah. Adanya interaksi kedua faktor menunjukkan pengaruh konsentrasi etanol tergantung pada faktor lama waktu ekstraksi dan atau sebaliknya.

Aktivitas antioksidan ekstrak tertinggi yakni $74,67 \pm 0,92 \%$ pada perlakuan konsentrasi etanol $80 \%$ dan lama ekstraksi 30 menit sedangkan aktivitas antioksidan ekstrak terendah yakni $45,71 \pm 2,04 \%$ pada perlakuan konsentrasi etanol $90 \%$ dan waktu ekstraksi 10 menit. Berdasarkan hasil tersebut, dapat dilihat bahwa semakin tinggi konsentrasi etanol dan semakin singkat waktu ekstraksi yang digunakan cenderung menurunkan nilai aktivitas antioksidan. Sedangkan pada konsentrasi etanol $70 \%$ dan semakin lama waktu ekstraksi yang digunakan cenderung meningkatkan nilai aktivitas antioksidan. Aktivitas antioksidan dipengaruhi oleh banyaknya senyawa fitokimia yang terekstrak seperti senyawa fenol dan flavonoid (Zeković et al., 2016). Kuersetin adalah flavonoid yang paling banyak terdapat dalam kulit bawang merah dan paling efektif sebagai penangkap radikal DPPH dan lebih cepat bereaksi daripada flavonoid yang lain seperti rutin dan kaemferol (Lee et al., 2014). Kombinasi etanol dan air dapat memaksimalkan hasil ekstrak senyawa antioksidan yang bersifat polar dan non-polar tetapi konsentrasi etanol yang terlalu tinggi juga dapat mempengaruhi kuantitas senyawa aktif yang terekstrak (Waszkowiak and Gliszczyńska-Świgło, 2016). Ekstraksi kuersetin dengan etanol $60 \%$ menghasilkan kuersetin paling tinggi dibanding dengan etanol yang lebih rendah atau lebih tinggi (Thuy et al., 2020). Pada penelitian ini aktivitas antioksidan tertinggi pada ekstraksi dengan etanol $80 \%$ dan waktu ekstraksi 30 menit. Ekstraksi dengan etanol 70 atau $90 \%$ nilai aktivitas antioksidan ekstrak lebih rendah.

Hasil penelitian ini menunjukkan semakin lama waktu ekstraksi maka aktivitas antioksidan yang dihasilkan dapat semakin besar karena semakin banyak komponen senyawa aktif yang terekstrak (Milutinović et al., 2014). Hal tersebut dikarenakan semakin lama waktu ekstraksi maka kontak antara pelarut dan bahan semakin lama sehingga pelarut akan berdifusi ke bahan sampai terjadi keseimbangan konsentrasi larutan di dalam dan di luar bahan (Vinatoru et al., 2017).

\section{Warna Ekstrak Kulit Bawang Merah}

Pengukuran warna dilakukan dengan menggunakan color reader yang dinyatakan sebagai nilai $L^{*}, a^{*}$, dan $b^{*}$. Menurut Pathare et al. (2013), nilai $L^{*}$ menyatakan tingkat kecerahan nilai 0 untuk hitam dan nilai 100 untuk warna putih. Nilai $a^{*}$ positif untuk warna merah dan nilai negatif untuk warna hijau, sedangkan nilai $b^{*}$ positif untuk warna kuning dan nilai negatif untuk warna biru.

Tabel 1. Nilai kecerahan $\left(L^{*}\right)$, warna merah $\left(a^{*}\right)$ dan warna kuning $\left(b^{\star}\right)$ ekstrak kulit bawang merah

\begin{tabular}{lccc}
\hline $\begin{array}{l}\text { Perlakuan } \\
\text { (Etanol (\%); } \\
\text { waktu (menit) }\end{array}$ & $\begin{array}{c}\text { Kecerahan } \\
\left(\mathrm{L}^{*}\right)\end{array}$ & $\begin{array}{c}\text { Merah- } \\
\text { hijau }\left(\mathrm{a}^{\star}\right)\end{array}$ & $\begin{array}{c}\text { Kuning-biru } \\
\left(\mathrm{b}^{\star}\right)\end{array}$ \\
\hline $70 ; 10$ & $26,2 \pm 0,25$ & $-0,7 \pm 0,40$ & $3,6 \pm 0,15$ \\
$70 ; 20$ & $26,2 \pm 0,12$ & $-1,0 \pm 0,44$ & $3,6 \pm 0,17$ \\
$70 ; 30$ & $26,3 \pm 0,00$ & $0,6 \pm 0,21$ & $4,0 \pm 0,12$ \\
$80 ; 10$ & $26,5 \pm 0,12$ & $-0,9 \pm 0,17$ & $3,7 \pm 0,17$ \\
$80 ; 20$ & $26,6 \pm 0,00$ & $-0,9 \pm 0,20$ & $3,9 \pm 0,06$ \\
$80 ; 30$ & $26,5 \pm 0,21$ & $0,3 \pm 0,60$ & $4,0 \pm 0,06$ \\
$90 ; 10$ & $26,6 \pm 0,35$ & $0,4 \pm 0,21$ & $3,9 \pm 0,15$ \\
$90 ; 20$ & $26,7 \pm 0,15$ & $0,5 \pm 0,32$ & $4,1 \pm 0,17$ \\
$90 ; 30$ & $26,3 \pm 0,15$ & $0,7 \pm 0,30$ & $4,3 \pm 0,06$ \\
\hline
\end{tabular}

Tingkat Kecerahan $\left(L^{*}\right)$

Rerata tingkat kecerahan $\left(L^{*}\right)$ yang diperoleh berdasarkan pengukuran menggunakan color reader pada ekstrak kulit bawang merah berkisar antara 26,226,7 . Nilai tersebut berada di bawah angka 50 yang merupakan nilai tengah antara warna gelap dan terang sehingga dapat disimpulkan bahwa warna dari ekstrak kulit bawang merah cenderung gelap. Rerata nilai tingkat kecerahan $\left(L^{*}\right)$ ekstrak kulit bawang merah dapat dilihat pada Tabel 1. Hasil analisa ragam menunjukkan bahwa nilai tingkat kecerahan ekstrak dipengaruhi oleh konsentrasi etanol $(a=0,05)$ tetapi tidak dipengaurhi oleh 
lama waktu ekstraksi $(a=0,05)$. Berdasarkan konsentrasi etanol, nilai tingkat kecerahan cenderung meningkat mulai dari etanol $70 \%$ hingga etanol $90 \%$. Sedangkan berdasarkan waktu ekstraksi, nilai tingkat kecerahan pada waktu ekstraksi 20 menit cenderung mengalami sedikit kenaikan dan kemudian cenderung mengalami penurunan pada lama ekstraksi 30 menit.

Hasil penelitian ini menunjukkan tingkat kecerahan ekstrak kulit bawang merah semakin tinggi dengan meningkatnya konsentrasi etanol. Tingkat kecerahan pada ekstrak kulit bawang merah yang cenderung berwarna gelap dengan nilai $L^{*}$ yang rendah menunjukkan bahwa sumbangan warna merah dari antosianin yang cukup tinggi (Fredotović and Puizina, 2019).

\section{Intensitas Warna Merah $\left(a^{*}\right)$}

Rerata intensitas warna merah $\left(\mathrm{a}^{*}\right)$ ekstrak kulit bawang merah berkisar antara $-0,9$ sampai 0,7 . Nilai tersebut berada pada kisaran nilai warna merah dan warna hijau sehingga menunjukkan bahwa ekstrak kulit bawang merah memiliki warna merah di titik yang rendah. Rerata nilai intensitas warna merah $\left(a^{*}\right)$ ekstrak kulit bawang merah dapat dilihat pada Tabel 1.

Hasil analisa ragam menunjukkan bahwa faktor konsentrasi etanol dan waktu ekstraksi berpengaruh nyata $(a=0,05)$ terhadap nilai warna merah ekstrak namun tidak terdapat interaksi $(a=0,05)$ antara faktor konsentrasi etanol dan waktu ekstraksi pada nilai warna merah ekstrak kulit bawang merah. Berdasarkan konsentrasi etanol, nilai warna merah pada konsentrasi etanol $80 \%$ cenderung menurun dan pada konsentrasi etanol $90 \%$ cenderung meningkat. Sedangkan berdasarkan waktu ekstraksi, nilai warna merah cenderung meningkat. Nilai rerata warna merah $\left(a^{*}\right)$ tertinggi yakni pada perlakuan konsentrasi etanol $90 \%$. Sedangkan nilai rerata warna merah terendah yakni pada perlakuan konsentrasi etanol $80 \%$. Nilai warna merah pada ekstrak kulit bawang merah konsentrasi $70 \%$ tidak berbeda nyata dengan konsentrasi $80 \%$. Hal ini menunjukkan peningkatan nilai warna merah pada ekstrak kulit bawang merah pada konsentrasi etanol $90 \%$. Semakin tinggi konsentrasi etanol, maka nilai warna merah semakin meningkat. Adanya peningkatan warna merah pada ekstrak dapat disebabkan karena meningkatnya jumlah antosianin sebagai pemberi pigmen warna merah pada ekstrak kulit bawang merah (Fredotović and Puizina, 2019). Pigmen warna merah pada kulit bawang merah dihasilkan dari antosianin terutama dari turunan sianidin dan peonidin (Cools et al., 2010). Nilai warna merah pada ekstrak kulit bawang merah waktu ekstraksi 10 menit tidak berbeda nyata dengan waktu ekstraksi 20 menit. Data hasil penelitian menunjukkan terjadinya peningkatan nilai warna merah pada ekstrak kulit bawang merah dengan waktu ekstraksi 30 menit. Hal ini menunjukkan bahwa semakin lama waktu ekstraksi yang digunakan, maka nilai warna merah semakin meningkat. Pada penelitian ini juga diperoleh nilai warna merah tertinggi pada waktu ekstraksi 30 menit. Meningkatnya tingkat kemerahan dapat terjadi karena semakin lama waktu ekstraksi maka jumlah antosianin yang terekstrak juga semakin banyak (Fredotović and Puizina, 2019).

\section{Intensitas Warna Kuning ( $\left.b^{*}\right)$}

Rerata intensitas warna kuning $\left(b^{\star}\right)$ ekstrak kulit bawang merah berkisar antara 3,6 sampai 4,3. Hasil analisa ragam menunjukkan bahwa faktor konsentrasi etanol dan waktu ekstraksi berpengaruh nyata $(a=0,05)$ terhadap nilai warna kuning ekstrak namun tidak terdapat interaksi $(a=0,05)$ antara faktor konsentrasi etanol dan waktu ekstraksi pada nilai warna kuning ekstrak kulit bawang merah. Berdasarkan konsentrasi etanol dan waktu ekstraksi, semakin tinggi konsentrasi etanol yang digunakan maka nilai warna kuning semakin meningkat.

Pada Tabel 1 menunjukkan bahwa nilai rerata warna kuning $\left(b^{*}\right)$ tertinggi yakni pada perlakuan konsentrasi etanol 90\%. Sedangkan nilai rerata warna kuning terendah yakni pada perlakuan konsentrasi etanol $70 \%$. Nilai warna kuning pada ekstrak kulit bawang merah konsentrasi $70 \%$ tidak berbeda nyata dengan konsentrasi $80 \%$. Hal ini menunjukkan semakin tinggi konsentrasi etanol, maka nilai warna kuning semakin meningkat. Kuersetin merupakan flavonoid yang paling banyak di kulit bawang merah yang mempunyai sifat kurang larut dalam air panas tetapi larut dalam etanol sehingga semakin tinggi konsentrasi etanol maka semakin banyak kuersetin yang terekstrak (David et al., 2016; Wiczkowski et al., 2008). Selain itu juga ada kontribusi meningkatnya jumlah antosianin sebagai pemberi pigmen warna pada ekstrak kulit bawang merah (Fredotović and Puizina, 2019).

Akibat pengaruh lama ekstraksi, nilai rerata warna kuning terendah yaitu pada perlakuan waktu ekstraksi 10 menit dan 20 menit di mana nilai warna kuning pada ekstrak kulit bawang merah waktu ekstraksi 10 menit tidak berbeda nyata dengan waktu ekstraksi 20 menit. Data hasil penelitian menunjukkan terjadinya peningkatan nilai warna kuning pada ekstrak kulit bawang merah dengan waktu ekstraksi 30 menit. Semakin lama waktu ekstraksi maka semakin banyak fitokimia yang terekstrak (Routray and Orsat, 2012).

Tabel 2. Koefisien korelasi Pearson ( $r$ ) dan $p$-value untuk total fenol dan total flavonoid terhadap aktivitas antioksidan

\begin{tabular}{lc}
\hline Parameter analisis & Aktivitas Antioksidan (\%) \\
\hline Total Fenol & $0,478^{\mathrm{a}}$ \\
& $0,012^{\mathrm{b}}$ \\
Total Flavonoid & $0,613^{\mathrm{a}}$ \\
& $0,001^{\mathrm{b}}$
\end{tabular}

Keterangan : a koefisien korelasi Pearson, ${ }^{b} p$-value $(p<0,05$ berbeda nyata)

\section{Efek Parameter Kimia Terhadap Aktivitas Antioksidan}

Nilai korelasi aktivitas antioksidan dengan total fenol yaitu $0,478(p=0,012)$ sedangkan nilai korelasi aktivitas antioksidan dengan total flavonoid yaitu 0,613 $(p=0,001)$ (Tabel 2). Hal ini menunjukkan beberapa senyawa fenol dan flavonoid dalam esktrak bawang merah menentukan aktivitas antioksidan. Senyawa flavonoid mempunyai korelasi yang lebih tinggi dibanding fenol yang artinya flavonoid lebih memberikan 
kontribusi dalam menentukan aktivitas antioksidan dibanding senyawa fenol. Senyawa flavonoid tersebut adalah kuersetin yang paling banyak ditemukan di kulit bawang merah dan mempunyai aktivitas antioksidan yang tinggi dibanding jenis flavonoid yang lain (Thuy et al., 2020). Kuersetin mempunyai gugus $\mathrm{OH}$ pada posisi ortho yang diketahui mempunyai aktivitas penangkapan radikal bebas yang lebih tinggi dari pada gugus $\mathrm{OH}$ pada posisi meta (Farvin dan Jacobsen, 2013).

\section{Kesimpulan}

Berdasarkan hasil penelitian yang diperoleh, faktor konsentrasi etanol dan lama waktu ekstraksi berpengaruh nyata terhadap parameter hasil ekstrak kulit bawang merah yaitu total fenol, total flavonoid, aktivitas antioksidan, intensitas warna merah dan intensitas warna kuning ekstrak kulit bawang merah. Kondisi ekstraksi dengan MAE yang menghasilkan total fenol dan flavonoid tertinggi adalah konsentrasi etanol $70 \%$ dan lama ekstraksi 20 menit.

\section{Daftar Pustaka}

Alara, O. R., Abdurahman, N.H., Olalere, O.A. 2018. Optimization of microwave-assisted extraction of flavonoids and antioxidants from Vernonia amygdalina leaf using response surface methodology. Food and Bioproducts Processing 107:36-48. DOI:10.1016/j.fbp.2017.10.007.

Bartsch, H., Gerhäuser, C. 2009. Molecular mechanisms of cancer induction and chemoprevention. Chemoprevention of cancer and DNA damage by dietary factors: 1-19. Wiley-VCH Verlag $\mathrm{GmBH}$ and Co.KGaA. DOI:10.1002/9783527626588.ch1.

Chan,C.H., Yusoff, R., Ngoh, G.C., Kung, F.W.L. 2011. Microwave-assisted extractions of active ingredients from plants. Journal Chromatography A 1218:6213-6225. DOI:10.1016/j.chroma. 2011.07.040.

Cools, K., Chope, G. A., Terry, L.A. 2010. Fate of flavonoids in the outer skins of onion (Allium cepa L.) throughout curing. Journal of Agricultural and Food Chemistry 58(22):11709-11715. DOI:10.1021/jf1028015.

Dahmoune, F., Boulekbache, L., Moussi, K., Aoun, O., Spigno, G., Madani, K. 2013. Valorization of citrus limon residues for the recovery of antioxidants: Evaluation and optimization of microwave and ultrasound application to solvent extraction. Industrial Crops and Products 50:77-87. DOI:10.1016/j.indcrop.2013.07.013.

David, A.A.V., Arulmoli, R., Parasuraman, S. 2016. Overviews of biological importance of quercetin: $A$ bioactive flavonoid. Pharmacognosy Reviews 10(20): 84-89. DOI:10.4103/0973-7847.194044.

Farvin, K. H. S., Jacobsen, C. 2013. Phenolic compounds and antioxidant activities of selected species of seaweeds from Danish coast. Food Chemistry 138:1670-1681. DOI:10.1016/ j.foodchem.2012.10.078.

Filip, S., Pavlić, B., Vidović, S., Vladić, J., Zeković, Z. 2017. Optimization of microwave-assisted extraction of polyphenolic compounds from ocimum basilicum by response surface methodology. Food Analytical Methods 10(7):2270-2280. DOI:10.1007/s12161-0170792-7.

Fredotović, Ž., Puizina., J. 2019. Edible Allium species: Chemical composition, biological activity and health effects. Italian Journal of Food Science 31 (1):19-39. DOI:10.14674/IJFS-1221.

Jin, E.Y., Lim, S., Kim, S O., Park, Y.S., Jang, J.K., Chung, M, S., Choi, Y,J. 2011. Optimization of various extraction methods for quercetin from onion skin using response surface methodology. Food Science and Biotechnology 20(6):17271733. DOI:10.1007/s10068-011-0238-8.

Kappe, C.O. 2004. Controlled microwave heating in modern organic synthesis. Angewandte Chemie International Edition English 43(46):6250-6284. DOI:10.1002/anie.200400655.

Koh Y.C., Ho C.T., Pan, M.H. 2020. Recent advances in cancer chemoprevention with phytochemicals. Journal of Food and Drug Analysis 28(1):14-37. DOI:10.1016/j.jfda.2019.11.001.

Lee, K.A., Kim, K.T., Kim, H.J., Chung, M.S., Chang, P.S., Park, H., Pai, H.D. 2014. Antioxidant activities of onion (Allium cepa L.) peel extracts produced by ethanol, hot water, and subcritical water extraction. Food Science and Biotechnology 23(2):615-621. DOI:10.1007/s10068-014-0084-6.

Mardiah, N., Mulyanto, C., Amelia, A., Lisnawati, L., Anggraeni, D., Rahmawanty, D. 2017. Penentuan aktivitas antioksidan dari ekstrak kulit bawang merah (Allium Ascalonicum L.) dengan metode DPPH. Jurnal Pharmascience 4(2):147-154. DOI:10.20527/jps.v4i2.5768.

Milutinović, M., Radovanović, N., Ćorović M., ŠilerMarinković S., Rajlić Stojano-vić M., DimitrijevićBranković, S. 2015. Optimisation of microwaveassisted extraction parameters for antioxidants from waste Achillea millefolim dust. Industrial Crops and Products 77:333-341. DOI:10.1016/j.indcrop.2015.09.007.

Milutinović, M., Radovanović, N., Rajlić-Stojanović, M., Šiler-Marinković, S., Dimitrijević, S., DimitrijevićBranković, S. 2014. Microwave assisted extraction for the recovery of antioxidants from waste Equisetum arvense. Industrial Crops and Products 61:388-397. DOI:10.1016/j.indcrop.2014.07.039.

Patel, A., Patel, A., Patel, A., Patel., N. M. 2010. Determination of polyphenols and free radical scavenging activity of Tephrosia purpurea linn leaves (Leguminosae). Pharmacognosy Research 2(3):152-158. DOI:10.4103/09748490.65509 .

Pathare, P. B., Opara, U.L., Al-Said, F.A.J. 2013. Colour measurement and analysis in fresh and processed foods: A review. Food and Bioprocess Technology 6(1):36-60. DOI:10.1007/s11947-012-0867-9.

Pavlović, M.D., Buntić, A.V., Šiler-Marinković, S.S., Dimitrijević-Branković, S.I. 2013. Ethanol influenced fast microwave-assisted extraction for 
natural antioxidants obtained from spent filter coffee. Separation and Purification Technology 118:503-510. DOI:10.1016/j.seppur.2013.07.035.

Pimentel-Moral, S., Borrás-Linares, I., Lozano-Sánchez, J., Arráez-Román, D., Martínez-Férez, A., Segura-Carretero, A. 2018. Microwave-assisted extraction for Hibiscus sabdariffa bioactive compounds. Journal of Pharmaceutical and Biomedical Analysis 156:313-322. DOI: 10.1016/j.jpba.2018.04.050.

Routray, W., Orsat, V. 2012. Microwave-assisted extraction of flavonoids: a review. Food and Bioprocess Technology 5(2):409424.DOI:10.1007/s11947-011-0573-z.

Schrenk, D., Gao, L., Lin, G., Mahony, C., Mulder, P. P. J., Peijnenburg, A.,Pfuhler, S., Rietjens, I. M. C. M., Rutz, L., Steinhoff, B ., These, A. 2020. Pyrrolizidine alkaloids in food and phytomedicine: Occurrence, exposure, toxicity, mechanisms, and risk assessment: A review. Food and Chemical Toxicology 136:1-13. DOI:10.1016/j.fct.2019. 111107.

Shi, G. Jing, Y., Jiang, L., Sheng-Nan, L., Han-Xue, S., Wen-En, Z., Yan-Qi, L. 2016. Isolation of flavonoids from onion skin and their effects on k562 cell viability. Bangladesh Journal Pharmacology 11:S18-S25. DOI:10.3329/bjp.v11i S1.26419.

Simić,V.M., Rajković,K.M., Stojičević. S., Veličković, D.T., Nikolić, N.Č., Lazić M.L., Karabegović, I.T. 2016. Optimization of microwave-assisted extraction of polyphenol compounds from chokeberries by response surface methodology and artificial neural network. Separation and Purification Technology 160:89-97. DOI:10.1016/j.seppur.2016.01.019.

Sun, C., Wu, Z., Wang, Z., Zhang, H. 2015. Effect of ethanol/water solvents on phenolic profiles and antioxidant properties of beijing propolis extracts. Evidence-Based Complementary and Alternative Medicine 2015: 95393.DOI:10.1155/2015/ 595393

Tabaraki, R., Nateghi, A. 2011. Optimization of ultrasonic-assisted extraction of nat-ural antioxidants from rice bran using response surface methodology. Ultrasonic Sonochemistry 18:1279-1286. DOI:10.1016/j.ultsonch. 2011.05. 004.

Tang, S.M., Deng, X.T., Zhou J., Li, Q.P., Ge, X.X., Miao, L. 2020. Pharmacological basis and new insights of quercetin action in respect to its anti-cancer effects. Biomedicine and Pharmacotherapy 121:17.DOI:10.1016/j.biopha.2019.109604.

Tatke, P., Jaiswal, Y. 2011. An overview of microwave assisted extraction and its application in herbal drug research. Research Journal of Medicinal Plants 5(1):21-31. DOI:10.3923/rjmp.2011.21.31.

Thuy, N.M., Tuyen, N.T.M., Cuong, N.P., Huyen, L.T.N., Phuong, N.P., Nguyen, L.T.T., Kim, J.H., Tai, N.V. 2020. Identification and extraction method of quercetin from flesh and skin of shallot (Allium ascalonicum) cultivated in Soc Trang province, Vietnam. Food Research 4(2):358-365. DOI:10.26656/fr.2017.4(2).306.

Vinatoru, M., Mason, T.J., Calinescu, I. 2017. Ultrasonically assisted extraction (UAE) and microwave assisted extraction (MAE) of functional compounds from plant materials. TrAC Trends in Analytical Chemistry 97:159-178.DOI:10.1016/ j.trac.2017.09.002.

Wang, Y., You, J., Yu, Y., Qu, C., Zhang, H., Ding, L., Zhang, H., Li, X. 2008. Analysis of ginsenosides in Panax ginseng in high pressure microwaveassisted extraction. Food Chemistry, 110(1):161167. DOI:10.1016/j.foodchem.2008.01.028.

Waszkowiak, K., Gliszczyńska-Świgło, A. 2016. Binary ethanol-water solvents affect phenolic profile and antioxidant capacity of flaxseed extracts. European Food Research and Technology 242(5):777-786. DOI:10.1007/s00217-015-25859.

Wiczkowski, W., Romaszko, J., Bucinski, A., SzawaraNowak, D., Honke, J., Zielinski, H., Piskula, M.K. 2008. Quercetin from shallots (Allium cepa $L$. var. aggregatum) is more bioavailable than its glucosides. The Journal of $\begin{array}{lll}\text { Nutrition 138(5):885- } & 888 . \quad \text { DOI:10.1093/ }\end{array}$ jn/138.5.885

Wolfe, K., Wu, X.F., Liu, R.H. 2003. Antioxidant activity of apple peels. Journal of Agricultural Food Chemistry 51(3):609-614. DOI:10.1021/ jf020782a.

Yuan, Y., Macquarrie, D. J. 2015. Microwave assisted step-by-step process for the production of fucoidan, alginate sodium, sugars and biochar from Ascophyllum nodosum through a biorefinery concept. Bioresources Technology 18:819-827. DOI:10.1016/j.biortech.2015.09.090.

Zeković, Z., Vladić, J., Vidović, S., Adamović, D., Pavlić., B. 2016. Optimization of microwave-assisted extraction (MAE) of coriander phenolic antioxidants - response surface methodology approach. Journal of The Science of Food and Agriculture 96(13):4613-4622. DOI:10.1002/jsfa. 7679.

Zhang, Q.W., Lin, L.G., Ye, W.C. 2018. Techniques for extraction and isolation of natural products: a comprehensive review. Chinese Medicine 13:2020. DOI:10.1186/s13020-018-0177-x. 